\title{
Naturally Occurring Co-infection of Avian Leukosis Virus (subgroups A-E) and Reticuloendotheliosis Virus in Green Peafowls (Pavo muticus)
}

\section{-Author(s)}

\section{Khordadmehr M \\ Firouzamandi $\mathrm{M}^{\prime}$ \\ Zehtab-Najafi M}

Shahbazi R

Department of Pathobiology, Faculty of Veterinary Medicine, University of Tabriz, Tabriz, Iran.

\section{ABSTRACT}

Most of the neoplastic diseases affecting poultry have a viral etiology, such as Marek's disease, avian leukosis/sarcoma and reticuloendotheliosis. In the present paper, histopathology and molecular methods were performed, in addition of necropsy and gross morphology evaluation, for the differential diagnosis of these diseases in two green peafowls (Pavo muticus). The affected birds showed nonspecific signs, such as depression, anorexia, and diarrhea. At necropsy, diffuse enlargement by several times the normal size of the liver and the spleen was observed. In one of the birds, the liver presented white to grayish discoloration was present, and focal and nodular growths in the other bird. Grossly, the other visceral organs and the peripheral nerves were normal. Microscopically, most of the tumor cells were large and uniform with pleomorphic nuclei. The PCR analysis for Marek's disease virus (MDV), avian leukosis virus (ALV), lymphoproliferative disease virus (LPDV), and reticuloendotheliosis virus (REV)based on their specific sequences showed the presence of ALV subgroups A-E and REV. According to these results, definitive diagnosis was co-infection of ALV and REV in naturally-infected green peafowls.

\section{INTRODUCTION}

Neoplasms of poultry are divided into two main categories: virusinduced neoplasms and neoplasms of unknown etiology (Nair, 2013). Unlike in human medicine, where the vast majority of cancers are noninfectious (Javier \& Butel, 2008; Braoudaki \& Tzortzatou-Stathopoulou, 2011), most of the neoplastic diseases affecting poultry have a viral etiology (Nair, 2013). There are three economically important virusinduced neoplastic diseases of poultry: Marek's disease (MD), caused by a herpesvirus, and avian leukosis/sarcoma (L/S) and reticuloendotheliosis (RE), caused by retroviruses (Nair, 2013). These diseases are responsible for economic loss due to both mortality and depressed performance (Payne \& Venugopal, 2000).

Virtually all poultry, including game fowl, are susceptible to MDV infection and tumor development. Quails, turkeys, pheasants, and some species of ducks and geese are also susceptible to infection and disease. Most other avian species, including sparrows, pigeons, and peafowl are probably refractory (Schat \& Nair, 2008). There has been one report of MDV in Roulroul partridges (Rollulus rouloul) (Haesendonck et al., 2015). Chickens are the natural hosts for all viruses of the L/S group; these viruses have not been isolated from other avian species, except for pheasants, partridges, and quails. The Rous sarcoma virus (RSV) has the widest host range; it causes tumors in chickens, pheasants, guinea fowl, ducks, pigeons, Japanese quails, turkeys, and rock partridges (Alectoris graeca) (Nair \& Fadly, 2013). There is one report of 
Khordadmehr M, Firouzamandi M, Zehtab-Najafi M, Shahbazi R
Naturally Occurring Co-infection of Avian Leukosis Virus (subgroups $A-E$ ) and Reticuloendotheliosis Virus in Green Peafowls (Pavo muticus) lymphoid leukosis (LL) in ostriches (Struthio camelus) (Garcia-Fernandez et al., 2000). REVs are, however, structurally, morphologically, and immunologically unrelated to the viruses of the avian L/S group of retroviruses (Witter \& Schat, 2003). Representative strains of the REV group include the replication of the defective $T$ strain and of the non-defective A strain, both of which were originally isolated from turkeys (Chen et al., 1987). Additional non-defective REV strains have been isolated from geese, pheasants, peafowl, Japanese quails, Greater prairie chickens (Tympanuchus cupido pinnatus), and Attwater's prairie chickens (Tympanuchus cupido attwateri) (Nair et al., 2013). Lymphoproliferative disease (LPD), another neoplastic disease of turkeys reported in Europe and Israel, is also induced by another retrovirus, which incidence is sporadic in turkeys (Nair, 2013).

Neoplastic diseases by these groups of viruses continue to cause serious disease and economic losses in many parts of the world. The differential diagnosis of these neoplastic diseases under natural conditions at necropsy is difficult. The two major lymphomatotic diseases, MD and $\mathrm{LL}$, are particularly confusing. Although REV-induced lymphomas are infrequent and generally arise from contaminated vaccines, REV could complicate the differential diagnosis of lymphomas (Nair, 2013). A diagnosis based on typical gross lesions should be confirmed histologically, or preferably by virus studies and appropriate molecular methods.

In the present paper, histopathology and molecular methods are applied, in addition to necropsy and gross morphology, for the definitive diagnosis of $M D, L L$, $R E$, and LPD in two naturally-infected immature green peafowls (Pavo muticus).

\section{MATERIALS AND METHODS}

\section{Case history}

Out of a group of eight immature green peafowls (Pavo muticus) with approximately 5 months of age, two birds died after developing non-specific signs for one month, which included depression, weight loss, paleness, anorexia, and diarrhea. All birds were kept in the backyard of a private home after hatching, and were fed a broiler feed containing soybean and corn. The peafowls had close contact with ten adult backyard chickens (about one-year old) which did not show any clinical signs or mortality at that time.

At necropsy, diffuse enlargement several times the normal size was observed in the liver and spleen. The liver and the spleen were first routinely processed for possible bacterial infection by seeding petri dishes with MacConkey Agar and Blood Agar, which incubated at $37^{\circ} \mathrm{C}$ for 24 hours. Then, the gross examination of visceral organs was carefully performed. In the liver of one bird, diffuse white to grayish discoloration was present (Figure 1A), while in the other bird, there were hepatic lymphomas as focal, nodular growths of varying sizes and white to gray in color (Figure 1B), that were firm with a smooth cut surface. Necrosis was rare and occurred in the center of growing lesions. Grossly, the other visceral organs, including lungs, heart, kidneys, bursa, and the genital and alimentary systems were normal. Also, enlarged peripheral nerves were not observed in both of the affected birds.

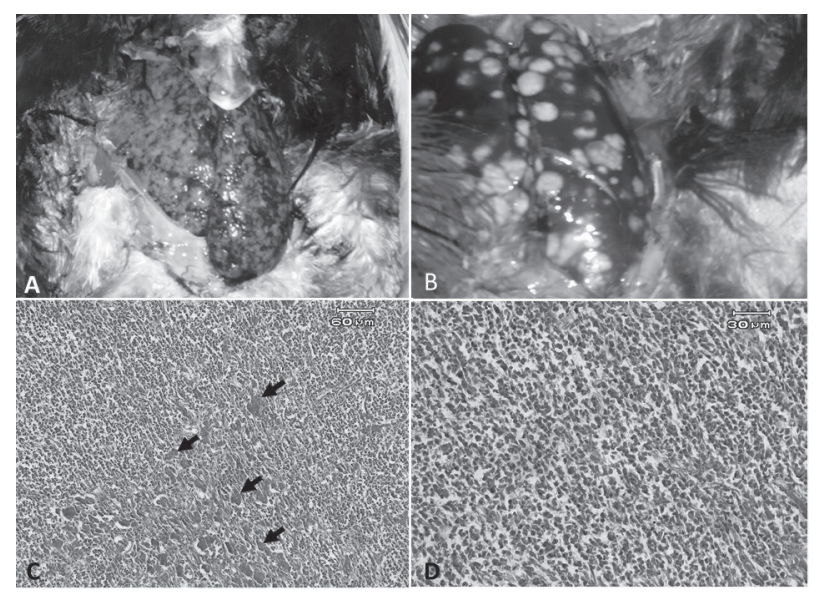

Figure 1 - Gross and microscopic features of the co-infection of green peafowl (Pavo muticus) with avian leukosis virus (ALV) and reticuloendotheliosis virus (REV). In the liver of one bird, diffuse white to grayish discoloration was present (A). However, in the other bird, hepatic lymphomas occurred as white to gray multifocal growths of varying size (B). Diffuse lymphoid cell infiltration of the liver caused loss of normal architecture; only a few degenerated hepatocytes were observed (C). Lymphomatous lesions were consisted of diffusely proliferating lymphocytes and lymphoblasts which are characterized by large and pleomorphic nuclei (D); (H\&E).

\section{Histopathology}

For histopathological examination, liver and spleen samples were fixed in 10\% neutral buffered formalin, dehydrated in graded ethanol series, cleared in xylol, embedded in paraffin wax and sectioned at about $5-\mu \mathrm{m}$. The sections were mounted on slides, stained with hematoxylin and eosin (H\&E) and examined by light microscopy.

\section{Molecular Diagnosis}

Two 10- $\mu \mathrm{m}$ thick sections were cut from each paraffin block using a rotary microtome (model RM2125, Leica Biosystems, USA), and total DNA was extracted using a previously described method (Campos \& Gilbert, 2012). Extracted DNA was used as a template with specific primers of MDV, REV, ALV and LPDV viruses for the PCR as previously described (Smith 
et al., 1998; Cao et al., 2013; Allison et al., 2014). Sequences of the primers used, including $\mathrm{MdCV} /$ pp38, REV long terminal repeat (LTR), ALV (H5/H7; H5/ $A D 1)$ and LPDV, are shown in Table 1. PCR reaction was carried out in $25 \mathrm{uL}$ reaction volumes, consisting of $12.5 \mu \mathrm{L}$ of Taq DNA Polymerase $2 x$ Master Mix (Ampliqon IIII, Denmark), 20 pmol of each primer, and 50-100 ng of template DNA. PCR program for REV (LTR) and MdCv was carried out as previously described (Cao et al., 2013). PCR program for ALV (H5/AD1and $\mathrm{H} 5 / \mathrm{H} 7$ ) was carried out as previously described (Smith et al, 1998). Also, the LPDV program was performed as previously described (Allison et al., 2014). All of the PCR products were analyzed on the $1.5 \%$ agarose gel.

\section{RESULTS}

\section{Macroscopic and microscopic appearance}

The results of the bacteriological examination of the liver and the spleen of both birds were negative. Moreover, in the histological examination, there were no lesions indicative of bacterial infection. Histologically, the enlarged organs showed diffuse or multifocal areas of proliferation of lymphoid cells (Figure1C) associated with reticular cells and fibers. The proliferation of the reticular tissues was associated with severe necrosis of the parenchyma, hemorrhage and congestion, especially in the liver. In the liver of the bird that showed diffuse white to grayish discoloration at gross examination, large coalescing areas of lymphoreticular infiltration were observed, while in the other bird, focal and nodular hepatic lesions and many focal areas of lymphoreticular infiltration were observed. Lymphomatous lesions consisted of proliferating uniform and large lymphoreticular cells and macrophages, whereas heterophils and plasma cells were rarely present. Tumor cells are characterized by large, pleomorphic nuclei with prominent nucleoli (Figure1D). The liver presented proliferation of reticular cells and fibers with necrosis and depletion of hepatocytes, resulting in loss of normal architecture.
In the spleen, proliferation of reticular tissues was observed around sheathed capillaries, which showed a prominent or hypertrophic endothelium. Moreover, ellipsoidal blood vessels were prominent, with deposition of fibrinoid substance and the lymphoid follicles had an atrophied appearance, with few large lymphocytes and loose outer capsule and normal structure. Also, there were fewer white pulp areas and further apart from each other and most of the splenic tissue was composed of the red pulp.

\section{PCR analysis}

DNA extraction from paraffin-embedded tissue blocks with storage time of 7 months was performed successfully. ALV subgroups A-E and also REV were detected in the paraffin-embedded spleen and liver samples of both peafowls. MdCv/pp38 primers were used as specific primers for the detection of MDV in the infected tissues. The results of our study showed that the primers successfully amplified the MDV positive control, but the DNA template was not able to amplify any fragments neither in spleen nor in liver of both studied peafowls. In addition, we used of $\mathrm{H} 7$ as reverse primer with $\mathrm{H} 5$ as forward primer for ALV subgroup J detection. Likewise, we could not obtain any amplified fragments on our studied DNA template neither in spleen nor in liver of both studied peafowls. Similarly, DNA was extracted for LPDV detection by PCR using specific primers (Allison et al., 2014). All of the studied samples were negative for LPDV (data not shown). In conclusion, we could not find any MDV and/ or LPDV contamination in the studied samples.

\section{DISCUSSION}

In the present paper, two green peafowls with no typical clinical signs and gross morphology of liver and spleen like MD and LL with no enlargement of peripheral nerves or changes in the bursa were examined. The microscopic appearance was vague and caused difficulty in tumor diagnosis. In the primary

Table 1 - Sequence of oligonucleotide primers, targets and expected PCR product sizes.

\begin{tabular}{|c|c|c|c|c|}
\hline Primer name & & Sequence $\left(5^{\prime}-3^{\prime}\right)$ & Product length (bp)/Amplification target & References \\
\hline $\mathrm{MdCv}$ & $\begin{array}{l}\text { Forward } \\
\text { Reverse }\end{array}$ & $\begin{array}{l}\text { GTGATGGGAAGGCGATAGAA } \\
\text { TCCGCATATGTTCCTCCTTC }\end{array}$ & 225/MDV-pp38 & Cao et al., 2013 \\
\hline SNV-LTR & $\begin{array}{l}\text { Forward } \\
\text { Reverse }\end{array}$ & $\begin{array}{l}\text { AATGGTTGTAAAGGGCAGAT } \\
\text { СTCСTCTCACTGCCAATCT }\end{array}$ & 200/REV-LTR & Cao et al., 2013 \\
\hline $\begin{array}{l}\text { H5 } \\
\text { H7 } \\
\text { AD1 }\end{array}$ & $\begin{array}{l}\text { Forward } \\
\text { Reverse } \\
\text { Reverse }\end{array}$ & $\begin{array}{c}\text { GGATGAGGTGACTAAGAAAG } \\
\text { CGAACCAAAGGTAACACACG } \\
\text { GGGAGGTGGCTGACTGTGT }\end{array}$ & $\begin{array}{l}\text { 545/Subgroup J ALV } \\
\text { 295-326b/Subgroups A-E ALV }\end{array}$ & Smith et al., 1998 \\
\hline LPDV & $\begin{array}{l}\text { Forward } \\
\text { Reverse }\end{array}$ & $\begin{array}{l}\text { ATGAGGACTTGTTAGATTGGTTAC } \\
\text { TGATGGCGTCAGGGCTATTTG }\end{array}$ & $\begin{array}{l}431 \mathrm{bp} / \text { covered a region spanning the p31 and } \\
\text { CA genes }\end{array}$ & Allison et al., 2014 \\
\hline
\end{tabular}




\section{Naturally Occurring Co-infection of Avian Leukosis Virus (subgroups A-E) and Reticuloendotheliosis Virus in Green Peafowls (Pavo muticus)}

histology study, the microscopic appearance of the liver and spleen was similar to MD type A lesions, as indicated by massive infiltration of lymphocytes and lymphoblasts, some plasma cells and a few macrophages, which caused loss of normal structure of the liver and spleen. There were large coalescing/focal areas of lymphoreticular infiltration in the liver. Also, proliferation of reticular cells and fibers associated with lymphatic depletion was observed in the spleen. Similar pathological findings were previously reported by Prezotto et al. (2016) in broiler chickens. To the authors' knowledge, this is the first report of ALV infection associated with REV in the peafowl, which belong the Phasianidae family. According to Nair \& Fadly (2013), subgroups A, B, C, and D of ALV have been isolated from commercial broiler flocks in Finland, subgroup $\mathrm{F}$ viruses in ring-necked (Phasianus colchicus) and green pheasants (Phasianus versicolor), subgroup $G$ viruses in Ghinghi, silver (Lophura nycthemera), and golden pheasants (Chrysolophus pictus), subgroup $\mathrm{H}$ virus in Hungarian partridges (Perdix perdix), and subgroup I virus in Gambel's quail (Callipepla gambelii).

The neoplastic diseases caused by the REV represent a third distinct etiological group of avian viral neoplasms, after MD and LL. REV has a wider host range compared with other avian tumor viruses and can infect or transform a variety of cell types. The various neoplastic syndromes induced by REV in chickens resemble both LL and MD (Nair et al., 2013). Naturally occurring clinical reticuloendotheliosis was previously reported in turkeys and chickens (Okoye et al., 1993) using histopathology and agar gel diffusion precipitation tests. In another previous study, orbital lymphosarcoma associated with reticuloendotheliosis virus in an Indian peafowl (Pavo cristatus) was reported based on histopathology and PCR tests (Miller et al., 1998).

The value of PCR for the diagnosis of poultry lymphomas is controversial (Witter \& Schat, 2003). In the affected peafowls examined in the present study, the gross and microscopic lesions were very confusing. Therefore, the molecular assay was performed based on the specific sequences for MDV, ALV, REV and LPDV for the present cases. DNA was successfully extracted from paraffin-embedded tissue blocks, in agreement with previous studies (Smith et al., 1998; Cao et al., 2013). The MDV antigens MdCv, Meq, pp38 and vIL8 were not expressed, neither the LPDV p31 and CA genes. However, the samples were positive for REV-LTR and also for ALV subgroups A-E, demonstrating the coinfection of the affected peafowls with ALV (subgroups A-E) and REV.
Immunosuppressive diseases usually negatively affect chickens in the poultry industry by increasing their susceptibility to opportunistic infections by viruses and bacteria (Balamurugan \& Kataria, 2006). Immunosuppression in chickens can be induced by many viruses, including MDV, ALV, REV and CAV (chicken anemia virus), which cause similar lesions, making their diagnosis in the field more difficult (Nair \& Fadly, 2013). Moreover, the possibility of co-infection makes it difficult to individually differentiate these immunosuppressive viral infections (Dong et al., 2014), such as the case of the confusing pathological findings in the present study. However, these immunosuppressive diseases and their subsequent secondary infections often affect commercial chickens. According to previous reports, the co-infection of REV with MDV is common in many countries; however, the mechanism of MDV- or REV-induced immunosuppression has not been fully elucidated (Davidson \& Boreshtain, 2001; Islam et al., 2002). Zheng et al. (2006) observed that an increase in the incidence of MD in broilers was associated with a simultaneous increase in the incidence of REV in chickens. Some researchers recently reported simultaneous endemic infections with ALV subgroup $\mathrm{J}$ and REV in commercial and local breeds of chickens in China (Cui et al., 2009). Another recent study also demonstrated the synergic pathological effects of the co-infection of CAV-MG (Mycoplasma gallisepticum) vaccine strains on experimentally-infected young SPF broiler chickens (Prezotto et al., 2016) based on pathology and molecular methods, like the present study. In the present study, it was not clear which virus first infected the birds. Since the REV-induced lymphomas are infrequent, we hypothesize that ALV infection lead to immunosuppression of the peafowls, which then became more susceptible to the secondary REV infection.

In conclusion, mixed infections make tumor diagnosis difficult. According to the recent reports, it seems that the mixed infections in viral neoplasms of poultry are frequent. Therefore, for definitive diagnosis, application of molecular methods is necessary, in addition to gross examination and histopathology. The present study has demonstrated the natural co-infection of green peafowls with two immunosuppressive viruses (ALV and REV) by the examination of gross and histopathological lesions and confirmatory molecular detection. As these viruses may contaminate other avian species and commercial poultry, they should be further studied. 
Khordadmehr M, Firouzamandi M, Zehtab-Najafi M, Shahbazi R
Naturally Occurring Co-infection of Avian Leukosis Virus (subgroups $A-E$ ) and Reticuloendotheliosis Virus in Green Peafowls (Pavo muticus)

\section{REFERENCES}

Allison AB, Keel MK, Phillips JE, Cartoceti AN, Munk BA, Nemeth NM, et al. Avian oncogenesis induced by lymphoproliferative disease virus: a neglected or emerging retroviral pathogen? Virology 2014;450-451:212.

Balamurugan V, Kataria JM. Economically important non-oncogenic immunosuppressive viral diseases of chicken-current status. Veterinary Research Communications 2006;30:541-566.

Braoudaki M, Tzortzatou-Stathopoulou F. Tumorigenesis related to retroviral infections. The Journal of Infection in Developing Countries $2011 ; 5: 751-758$

Campos PF, Gilbert TMP. DNA Extraction from formalin-fixed material. Methods in Molecular Biology 2012;840:81-85.

Cao W, Mays J, Dunn J, Fulton R, Silva R, Fadly AM. Use of polymerase chain reaction in detection of marek's disease and reticuloendotheliosis viruses in formalin-fixed, paraffin-embedded tumorous tissues. Avian Diseases 2013;57:785-789.

Chen PY, Cui Z, Lee LF, Witter RL. Serologic differences among non defective reticuloendotheliosis viruses. Archive of Virology 1987;93:233-245.

Cui Z, Sun S, Zhang Z, Meng S. Simultaneous endemic infections with subgroup J avian leukosis virus and reticuloendotheliosis virus in commercial and local breeds of chickens. Avian Pathology 2009;38(6):443-448.

Davidson I, Boreshtain R. In vivo events of retroviral long terminal repeat integration into Marek's disease virus in commercial poultry: detection of chimeric molecules as a marker. Avian Diseases 45;102-121, 2001.

Dong X, Ju S, Zhao P, Li Y, Meng F, Sun P et al. Synergetic effects of subgroup $\mathrm{J}$ avian leukosis virus and reticuloendotheliosis virus co-infection on growth retardation and immunosuppression in SPF chickens. Veterinary Microbiology 2014;172:425-431.

Garcia-Fernandez RA, Perez-Martinez C, Espinosa-Alvarez J, Escudero-Diez A, Garcia-Marin JF, Nunez A, et al. Lymphoid leukosis in an ostrich (Struthio camelus). Veterinary Record 2000;146:676-677.

Haesendonck R, Garmyn A, Dorrestein GM, Hellebuyck T, Antonissen G, Pasmans F, et al. Marek's disease virus associated ocular lymphoma in Roulroul partridges (Rollulus rouloul). Avian Pathology 2015;44(5):347351.

Islam AF, Wong CW, Walkden-Brown SW, Colditz IG, Arzey KE, Groves PJ. Immunosuppressive effects of Marek's disease virus (MDV) and herpesvirus of turkeys (HVT) in broiler chickens and theprotective effect of HVT vaccination against MDV challenge. Avian Pathology 2002:31:449-461.
Javier RT, Butel JS. The history of tumor virology. Cancer Research 2008;68:7693-7706.

Miller PE, Paul-Murphy J, Sullivan R, Cooley J, Dubielzig RR, Murphy CJ, et al. Orbital lymphosarcoma associated with reticuloendotheliosis virus in a peafowl. Journal of the American Veterinary Medical Association 1998;213(3):377-380

Nair V. Neoplastic diseases. In: Swayne DE, Glisson JR, McDougald LR, Nolan LK, Suarez DL, Nair N. Diseases of poultry. $13^{\text {th }}$ ed. New York: John Wiley \& Sons; 2013. p. 514

Nair V, Fadly AM. Neoplastic diseases: leukosis/ sarcoma group. In: Swayne DE, Glisson JR, McDougald LR, Nolan LK, Suarez DL, Nair N. Diseases of poultry $.13^{\text {th }}$ ed. New York: John Wiley \& Sons; 2013. p. 566- 576.

Nair V, Zavala G, Fadly AM. Neoplastic diseases: Reticoloendotheliosis. In: Swayne DE, Glisson JR, McDougald LR, Nolan LK, Suarez DL, Nair N. Diseases of poultry. $13^{\text {th }}$ ed. New York: John Wiley \& Sons; 2013. p. 593-604.

Okoye JOA, Ezema W, Agoha JN. Naturally occurring clinical reticuloendotheliosis in turkeys and chickens. Avian Pathology $1993 ; 22: 237-244$

Payne LN, Venugopal K. Neoplastic diseases: Marek's disease, avian leukosis and reticuloendotheliosis. Revue scientifique et technique International Office of Epizootics 2000;19(2):544-564.

Prezotto CF, Marin SY, Araujo TS, Barbosa FO, Barrios PR, Gomes AM, Peconick AP, Resende M, Sousa RV, Martins NRS. Experimental coinfection of chicken anemia virus and mycoplasma gallisepticum vaccine strains in broiler chicks. Brazilian Journal of Poultry Science 2016;18(3):475-480.

Schat KA, Nair V. Neoplastic diseases: Marek's disease. In: Swayne DE, Glisson JR, McDougald LR, Nolan LK, Suarez DL, Nair N. Diseases of poultry. $13^{\text {th }}$ ed. New York: John Wiley \& Sons; 2103. p.515-539.

Smith LM, Brown SR, Howes K, McLeodS, Arshad SS, Barron GS, et al. Development and application of polymerase chain reaction (PCR) tests for the detection of subgroup J avian leukosis virus. Virus Research 1998;54:87-98.

Witter RL, Schat KA. Marek's disease In: Saif YM, Barnes HJ, Fadly AM, Glisson JR, McDougald LR, Swayne DE, editors. Diseases of poultry. Ames: lowa State University Press; 2003. p.407-465

Zheng Y, Cui Z, Zhao P, Li H, Liu C, Tian Z, et al. Effects of reticuloendotheliosis virus and Marek's disease virus infection and co-infection on INFgamma production in SPF chickens. The Journal of Veterinary Medical Science 2007;69(2):213-216 
